\title{
Pengaruh Modal Terhadap Pendapatan Pedagang (Studi kasus: Pasar Angso Duo Kota Jambi)
}

\author{
Sudirman, Ubaidillah \\ Fakultas Ekonomi Universitas Batanghari Jambi \\ Correspondence email: sudirman@unbari.ac.id, ubaidillah@unbari.ac.id
}

\begin{abstract}
Abstrak_Penelitian ini bertujuan untuk megetahui pengaruh variabel modal terhadap pendapatan pedagang di Pasar Angso Duo Kota Jambi. Dalam penelitian ini menggunakan data primer dengan cara menyebarkan qusioner kepada 92 responden. Adapun metode yang digunakan dalam penelitian ini adalah metode regresi linier sederhana. sedangkan Analisis ekonometri dengan menggunakan model regresi linier sederhana dilakukan untuk mengidentifikasi variabel-variabel yang mempengaruhi. Variable yang digunakan adalah variable modal sebagai variable bebas dan variable pendapatan sebagai variable terikat. Hasil analisis menunjukkan bahwa modal berpengaruh positif terhadap pendapatan pedagang Pasar Angso Duo. Hal ini berarti jika pedagang pasar menambah modalnya, maka pendapatan pedagang pasar juga akan bertambah.
\end{abstract}

Kata kunci: modal, pedagang, pasar

Abstract_research aims to find out the effect of variable capital on the income of traders in Angso Duo Market Jambi City. The study used primary data by disseminating qusioners to 92 respondents. The method used in this study is a simple linear regression method. while econoetry analysis using a simple linear regression model is carried out to identify the variables that affect. Variables used are capital variables as free variables and income variables as bound variables. The results of the analysis showed that the capital had a positive effect on the earnings of Angso Duo Market traders. This means that if the market trader increases his capital, then the income of the market trader will also increase.

Keywords: capital, trader, market

\section{PENDAHULUAN}

Sukirno, (2000) Perdagangan adalah suatu aktivitas jual beli yang bertujuan untuk memperoleh keuntungan. Usaha perdagang dapat dimulai dari unit terkecil hingga antar negara. Perdagangan yang unit terkecil contohnya adalah perdagangan warung kelontong atau bisa juga perdagangan asongan di tepi jalan. Perdagangan dalam tingkat antar negara berkaitan dengan ekspor-import antar negara yang melibatkan berbagai kebijakan yang tidak dapat di ubah secara spesifik. Pedapatan suatu negara juga akan bertambah banyak ketika perdagangan antar negara ini di tingkatkan secara signifikan. Pengertian pedagang secara etimologi adalah orang yang berdagang atau bisa juga di sebut saudagar. Pedagang adalah orang-orang yang melakukan kegiatan-kegiatan perdagangan sehari-hari sebagai mata pencarian mereka untuk memenuhi kebutuhannya.

Widiastuti dalam sudirman (2018). Pembangunan merupakan tugas bersama yang harus dilaksanakan masyarakat Indonesia dengan tujuan untuk mewujudkan kemakmuran dan kesejahteraan masyarakat Indonesia pada umumnya serta masyarakat daerah pada khususnya. Pembangunan daerah merupakan bagian intregal dari pembangunan nasional yang diarahkan untuk memacu pemerataan pembangunan dan hasilhasilnya dalam rangka meningkatkan kesejahteraan dan peran aktif masyarakat serta meningkatkan pendayagunaan potensi daerah secara optimal.

Irawan \& Suparmoko,(1992).Masalah pokok bidang kependudukan di Indonesia adalah perkembanganpenduduk yang relatif tinggi, adanya struktur umur yang tidak seimbang, distribusi pendapatan yang tidak merata dan kualitas tenaga kerja yang rendah.

Sukirno, (2000). Pembangunan ekonomi merupakan suatu proses yang menyebabkan pendapatan perkapita penduduk suatu masyarakat meningkat dalam jangka panjang.

Jumlah pedaganng yang berada di Pasar Angso Duo Kota Jambi berdasarkan tempat berdagang di sajikan bisa di lihat pada tabel sebagai berikut.

Tabel 1. Jumlah Pedagang Berdasarkan Tempat Dagang di Pasar Angso Duo, Kota Jambi Tahun 2019

\begin{tabular}{|c|l|c|}
\hline No & Tempat Dagang & Jumlah Pedagang (orang) \\
\hline 1 & Kios & 384 \\
\hline 2 & Los Amparan & 0 \\
\hline 3 & Ruko & 0 \\
\hline \multicolumn{2}{|c|}{ Jumlah } & 384 \\
\hline
\end{tabular}

Sumber : Dinas Pengelolaan Pasar Angso Duo (2019)

Damariyah, (2015). Sektor informal memberikan kemungkinan kepada tenaga kerja yang berlebih di pedesaaan migrasi dari kemiskinan dan pengangguran. Sektor informal sangat berkaitan dengan sektor formal di perkotaan. Sektor formal tergantung pada sektor informal terutama dalam hal input mudah dan menyediakan baran-barang bagi pekerja di sektor formal. Sebaliknya sektor informal tergantung dari pertumbuhan di sektor formal. Sektor informal kadang-kadang justru mensubsidi sektor formal dengan menyediakan barangbarang dan kebutuhan dasar yang murah bagi pekerja di sektor formal. Sektor informal mempunyai peranan yang 
penting dalam mengurangi tingkat pengangguran karena pelaku sektor informal menciptakan lapangan pekerja sendiri dan memiliki pendapatan yang cukup untuk menghidupi semua tanggungan mereka.

\section{Teori Pendapatan}

Sukirno, (2000). Pendapatan atau keuntungan ekonomi adalah pendapatan total yang diperoleh pengusaha setelah dikurangi oleh biaya produksi. Pendapatan merupakan hasil yang didapatkan melalui kegiatan suatu usaha yaitu kegiatan jual beli dengan melakukan transaksi antara penjual dan pembeli dengan adanya kesepakatan bersama.

Samuelson \& Nordhaus, (2003). Pendapatan yang diterima adalah dalam bentuk uang, dimana uang merupakan alat pembayaran dan alat penukaran.

Swasta dan Irawan (2008:201) mengatakan bahwa faktor-faktor yang mempengaruhi pendapatan dari kegiatan penjualan antara lain: (1) kondisi dan kemampuan pedagang; (2) transaksi jual beli yaitu mampu menyakinkan para pembeli untuk membeli dagangannya dan sekalipun memperoleh pendapatan yang diinginkan; (3) kondisi pasar; (4) modal; (5) kondisi organ- isasi penjualan; (6) faktor lain seperti periklanan, peragaan, kampanye, pemberian hadiah sering mempengaruhi penjualan.

Boediono, (2002). secara garis besar pendapatan digolongkan menjadi ti- ga, yaitu (1) gaji dan upah; (2) pendapatan dari usaha sendiri; (3) pendapatan dari usaha lain.

Gilarso, (1992). menyebutkan pendapatan keluarga dapat di- peroleh melalui berbagai sumber di an- taranya (1) usaha sendiri (wiraswasta) contohnya berdagang, mengerjakan garapan la- han, dan menjalankan perusahaannya sendiri; (2) bekerja pada orang lain, contohnya bekerja dikantor atau perusahaan se- bagai karyawan baik swasta maupun di golongan pemerintah; (3) hasil dari milik sendiri, contohnya memiliki sawah, rumah yang dikontrakkan atau dibuat kost, memiliki uang yang dipinjamkan dengan bunga, gaji pensiunan bagi mereka yang sudah lanjut usia, dan dahulunya bekerja baik pada pemerintah atau instansi lainnya; (4) sumbangan atau hadiah, contohnya mendapatkan sumbangan atau bantuan dari keluarga, warisan orang tua, hadiah, tabungan dan lain-lain; (5) pinjaman atau hutang yaitu merupakan uang masuk tetapi pada suatu saat harus dikembalikan atau dilunasi.

Nurdiman (Patty, 2015) pendapatan adalah nilai yang di dapat dari suatu usaha yang telah di laksanakan dalam kurun waktu tertentu.

Marbun, (2003). Dalam kamus besar bahasa Indonesia pendapatan adalah hasil kerja (usaha atau sebagainya). Sedangkan dalam kamus manajemen adalah uang yang di terima oleh perorangan, perusahaan dan organisasi lain dalam bentuk upah, gaji, sewa, bunga, konsumsi, ongkos dan laba .
BPS, (2012). Pendapatan adalah keseluruhan penghasilan yang di terima baik dari sektor formal maupun nonformal yang di hitung dalamjangka waktu tertentu., mengukur pendapatan masyarakat bukanlah hal yang mudah, oleh karena itu BPS melakukan mengelolah perhitungan pendapatan dengan menggunakan pengeluaran/konsumsi mayarakat. Apabila pendapatan mengalami kenaikan maka akan di ikuti oleh kebutuhan yang semakin banyak dan pengeluaran yang tinggi.

Soekartawi, (2015). menjelaskan pendapatan akan mempengaruhi banyaknya barang yang di konsumsikan, bahwa sering kali di jumpai dengan bertambahnya pendapatan, maka barang yang di konsumsi bukan saja bertambah, tetapi juga kualitas barang tersebut ikut menjadi perhatian.

\section{Pedagang}

Tantri, (2008). Para pedagang dari zaman dahulu sampai sekarang sangat populer di negara kita. Pedagang dalam arti positif dan juga negatif. Dalam hal positif pedagang secara pasti dapat menyerap lapangan pekerjaan, dari sekian banyak pengangguran. Para penganggur ini mencoba untuk berkreasi, berwirausaha, dengan modal sendiri ataupun tanpa modal.

Pedagang sangat membantu konsumen, mudah mendapat barang, servis cepat, sambil lewat di kaki merek yang di tawarkan, biasanya mula-mula tinggi, tetapi akhirnya dapat penjual merasa mendapat keuntungan.

Pedagang merupakan suatu kelengkapan kotakota di seluruh dunia dari masa dahulu. Sebagai suatu kelengkapan, pedagang kaki lima tidak mungkin di hindari atau di tiadakan karena itu kalau ada suatu pemerintahan kota ingin meniadakan pedagang kaki lima akan menjadi kebijaksanaan atau tindakan yang sia-sia.

Di samping kekuatan yang di milikinya, sektor informal juga memiliki kelemahan-kelemahan. Dengan kelemahan itu tentunya menyebabkan sektor informal akan mengalami kesulitan. Kendala-kendala yang banyak di alami pengusaha-pengusaha di sektor informal terutama adalah keterbatasan modal, khususnya modal kerja. Kendala lain adalah kesulitan pemasaran dan penyedian-penyedian bahan baku, keterbatasan sumber daya manusia, pengetahuan minim mengenai bisnis dan, dan kurang penguasaan teknologi.

\section{Modal}

Soekartiwi, (2015). Modal tidak bergerak (biasanya disebut dengan modal tidak tetap atau modal variabel). Modal tidak tetap adalah biaya yang di keluarkan dalam proses produksi dan habis dalam satu kali dalam proses produksi tersebut, misalnya biaya produksi yang di keluarkan untuk membeli seperti sayur, daging, dan kebutuhan-kebutuhan lainnya .

Firdaus, (2012). Pada saat untuk memulai suatu usaha baru yang di ajalnkan, biasanya lebih menitik 
beratkan pada modal itu sendiri. Hal ini terjadi karena sulit memperole modal pinjaman, terumata dari bank. Modal merupakan sejumlah uang yang akan di gunakan untuk memulai suatu usaha. Modal juga merupakan input (faktor produksi) yang sangat penting dalam menetukan tinggi rendahnya pendapatan. Tetapi bukan berarti merupakan faktor satu-satunya yang dapat meningkatkan pendapatan.

Menurut Kasmir (2009) berdasarkan sumbernya modal terbagi menjadi dua, yaitu:

1. Modal sendiri adalah modal yang berasal dari dalam perusahaan sendiri. Kelebihan dari modal ini adalah tidak memiliki beban biaya bunga dalam membiayai suatu usaha walaupun tetap harus membayar dividen. Pembayaran dividen tergantung keuntungan yang di peroleh dan hanya di bayar apabila telah memperoleh keuntungan. Modal ini di peroleh dari pemilik perusahaan dengan cara mengeluarkan saham yang dapat di lakukan secara saham tertutup ataupun saham terbuka. Namun biasanya modal sendiri memiliki jumlah yang terbatas serta sulit untuk memperolehnya.

2. Modal asing adalah modal yang bersumber dari luar perusahaan, misalnya modal yang berupa pinjaman dari bank. Keuntungan dari modal ini karena memiliki jumlah yang tidak terbatas. Modal pinjaman ini digunakan untuk membiayai suatu usaha. Modal ini menimbulkan beban biaya bunga, biaya administrasi, serta biaya provisi dan komisi dan mewajibkan pengembalian pinjaman dalam jangka waktu tertentu. Modal pinjaman akan menimbulkan motivasi pada pihak manajemen shingga dalam melakukan kegiatan usahanya dilakukan secara sungguh-sungguh sumber modal asing dapat berasal dari pinjaman dunia perbankan, lembaga keuangan, dan dari peusahaan non keuangan.

\section{METODE}

\section{Penelitian yang Digunakan}

Metode penelitian yang di gunakan adalah studi kasus (case study).

\section{Metode Analisis Data}

Pada penelitian ini penelitian menggunakan metode analisis regresi berganda (multiple regresion) karena penelitian ini menggunakan variabel multivariat dengan satu variabel dependen yang bersifat matrik. Metode analisis ini bergunaka untuk mengetahui seberapa besar pengaruh variabel independen terhadap variabel dependen.

Adapun model persamaan regresi yang digunakan dalam penelitian ini adalah sebagai berikut :

$$
\begin{aligned}
& \mathrm{Y}=\mathrm{a}+\mathrm{bX}+\mathrm{e} \\
& \text { Dimana : } \\
& \mathrm{Y}=\text { Pendapatan Pedagang } \\
& \mathrm{X}=\text { Modal } \\
& \mathrm{a}=\text { Konstanta } \\
& \mathrm{e}=\text { margin erorr }
\end{aligned}
$$

\section{Uji Statistik t}

Untuk melihat apakah koefisien regresi signifikan atau tidak, maka dilakukan uji dengan alat uji t statistik. Uji ini dimaksud untuk mengetahui signifikan pengaruh variabel independen terhadap variabel dependen yaitu apakah Moda (X), terhadap Pendapatan Pedagang (Y). Adapun rumus hipotesis yang di ujikan dalam penelitian ini adalah sebagai berikut:

$\mathrm{H}_{0}: \beta=0 \quad$ Artinya tidak terdapat pengaruh yang signifikan anatara variabel $\mathrm{X}$ terhadap variabel $\mathrm{Y}$.

$\mathrm{H}_{\mathrm{a}}: \beta \neq 0 \quad$ Artinya terdapat pengaruh yang signifikan antara variabel $\mathrm{X}$ terhadap variabel $\mathrm{Y}$.

Nilai t-hitung dapat diperbolehkan dengan rumus sebagai berikut:

$$
\mathbf{t}=\frac{\beta i}{\operatorname{Se}(\beta i)}
$$

Dimana :

$\mathrm{B}=$ Koefisien regresi hasil estimasi

$\mathrm{Se}=$ Simpangan baku atau standar eror

Berdasarkan perbandingan anatara nilai signifikansi yang didapat dengan derajat kepercayaan $(\alpha)$ yaitu 0,05 .

a. Jika $t_{\text {hitung }}>$ maka Ha diterima dan $\mathrm{H}_{0}$ ditolak berarti variabel independen ( Modal) secara bersama-sama mempunyai pengaruh yang signifikan terhadap variabel dependen (Pendapatan Pedagang).

b. Jika thitung $<$ maka $\mathrm{H}_{0}$ diterima dan Ha ditolak berarti variabel independen ( Modal) secara bersama-sama tidak mempunyai pengaruh yang signifikan terhadap variabel dependen (Pendapatan Pedagang).

Analisis regresi sederhana dalam penelitian ini dilakukan dengan menggunakan bantuan program SPSS Versi 22

\section{HASIL DAN PEMBAHASAN}

Tabel 2. Coefficients

Coefficients $^{\mathrm{a}}$

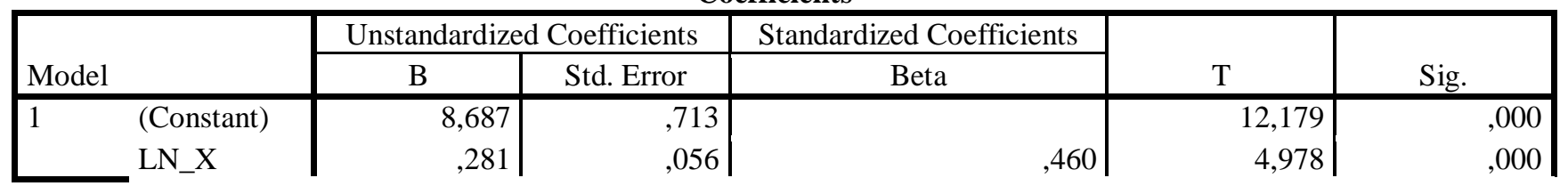

a. Dependent Variable: LN_Y 
Variabel modal (X) mempunyai nilai $\mathrm{t}_{\text {hitung }}$ sebesar 4,978 dan nilai signifikansi untuk variabel modal adalah 0,000 dinyatakan lebih kecil dari taraf $\alpha=0,05(0,000<$ $0,05)$. Hal ini menunjukkan juga dengan nilai $t_{\text {hitung }}=$ 4,978 dan nilai $t_{\text {tabel }}$ dengan tingkat signifikan dimana $\mathrm{df}$ $=$ jumlah sampel-jumlah variabel 5\% $(0,05) \mathrm{df}=94$ adalah adalah 1,985, sehingga $t_{\text {hitung }}>t_{\text {tabel }}(4,978>$ 1.985). Dari hasil tersebut sehingga dapat disimpulkan bahwa variabel modal mempunyai pengaruh positif dan signifikansi terhadap pendapatan pedagang.

\section{Koefisien Determinasi $\left(\mathbf{R}^{2}\right)$}

Koefisien determinasi $\left(\mathrm{R}^{2}\right)$ ini digunakan untuk menguji kecocokan dan ketetapan model. Jika $\mathrm{R}^{2}$ semakin mendekati angka 1 (satu) yang berarti koefisien determinasi $\left(\mathrm{R}^{2}\right)$ nilainya semakin tepat dan sebaliknya jika $\mathrm{R}^{2}$ menunjukkan angka 0 (nol) tidak tepat menaksir garis linier tersebut. Berikut ini hasil dari perhitungan nilai koefisiensi determinasi $\left(\mathrm{R}^{2}\right)$ dengan perhitungan SPSS Versi 22 sebagai berikut:

Tabel 3. Koefisien Determinasi $\left(\mathbf{R}^{2}\right)$ Model Summary ${ }^{\mathrm{b}}$

\begin{tabular}{|l|c|r|r|c|}
\hline Model & R & R Square & $\begin{array}{c}\text { Adjusted R } \\
\text { Square }\end{array}$ & $\begin{array}{c}\text { Std. Error of the } \\
\text { Estimate }\end{array}$ \\
\hline 1 &, $535^{\mathrm{a}}$ &, 286 &, 263 &, 08763 \\
\hline
\end{tabular}

a. Predictors: (Constant), LN

b. Dependent Variable: LN_Y

Koefisien determinasi menujukkan seberapa besar variabel terikat yang dapat dijelaskan oleh variabel bebas. Berdasarkan hasil analisis regresi linier sederhana diperoleh nilai koefisien determinasi $\left(\mathrm{R}^{2}\right)$ sebesar 0,286 menunjukkan bahwa 28,6\% variabel terikat mampu dijelaskan oleh variabel bebas yang dimasukkan kedalam model (modal), sedangkan sisanya sebesar $71,4 \%$ dipengaruhioleh faktor lain yang tidak dimasukkan dalam model.

Uji koefisien korelasi dimaksudkan untuk mengetahui seberapa besar keterkaitan hubungan antara variabel independen terhadap variabel dependen. Nilai $R$ akan berada pada $0<\mathrm{r}<1$, atau semakin mendekati 0 (nol) maka semakin lemah jika mendekati 1 (satu) semakin kuat.

Dari pehitungan statistik diperoleh nilai koefisien korelasi $\mathrm{R}$ sebesar 0,535 , artinya terdapat hubungan yang cukup kuat antara variabel bebas (modal, jam kerja dagang, dan lama dagang) dengan variabel terikat (pendapatan pedagang) sangat kuat).

\section{Pengaruh Modal (X) Terhadap Pendapatan Pedagang \\ Berdasarkan hasil penelitian terdapatan pengaruh antara modal $(\mathrm{X})$ terhadap pendapatan $(\mathrm{Y})$ dengan nilai signifikansi pada variabel modal sebesar $0,000<0,05$, maka, menunjukkan adanya pengaruh signifikansi dari variabel modal terhadap pendapatan pedagang.}

Penelitian ini menemukan bahwa secara parsial modal mempengaruhi pendapatan pedagang secara positif. Artinya semakin banyak jumlah modal akan meningkatkan pendapatan pedagang di Pasar Angso Duo Kota Jambi. Artinya meningkatkan modal disebabkan oleh meningkatnya pendapatan pedagang sehingga pedagang mempunyai kemampuan yang tinggi untuk menambah persedian sayur untuk diperjualkan, yang akan meningkatkan pendapatan pedagang di Pasar Angso Duo.

Menurut soekartawi (2015) yang kaitan antara modal dan produksi, dalam kegiatan produksi membutuhkan adanya faktor produksi salah satunya adalah modal. Bila moda; meningkat maka produksi meningkat. Hal ini menunjukkan kepada kita bahwa dalam peningkatan output harus diiringin dengan peningkatan input, salah satu input yang dibutuhkandalam proses produksi merupakan modal. Dengan demikian temuan penelitian ini membuktikan bahwa peningkatan dari modal pedagang memberikan pengaruh positif dalam meningkatkan produksi sayur dan meningkatkan pendapatan pedagang.

Hasil penelitian ini sesuai dengan penelitian yang dilakukan oleh Patty, Forlin Natalia dan Maria Rio Rita (2015) tentang faktor-faktor yang mempengaruhi pendapatan pedagang kaki lima.

\section{Implikasi Kebijakan}

Berdasarkan Undang-Undang Nomor 7 Tahun 2014 tentang perdagangan dan ketentuan, Pedagang adalah orang-orang yang melakukan kegiatan-kegiatan perdagangan sehari-hari sebagai mata pencarian mereka untuk memenuhi kebutuhannya.

Mengingatkan sebagian besar masyarakat di Pasar Angso Duo Kota Jambi adalah pedagang,maka hasil perkebunan memegang peran penting dalam kehidupan berdagang tersebut, karema pendapatan pedagang tergantung dari hasil panen perkebunan. Oleh karena itu, diperlukan adanya kebijakan terhadap kegiatan perkebunan dalam rangka meningkatkan kesejahteraan pedagang.

\section{SIMPULAN}

Berdasarkan hasil penelitian yang telah dilakukan pada 97 responden Pedagang di Pasar Angso Duo Kota Jambi. Maka dapat ditarik kesimpulan sebagai berikut hasil analisis menunjukkan bahwa modal berpengaruh positif terhadap pendapatan pedagang Pasar Angso Duo. Hal ini berarti jika pedagang pasar menambah modalnya, maka pendapatan pedagang pasaran juga akan bertambah.

\section{DAFTAR PUSTAKA}

Badan Pusat Statistik Provinsi Jambi 2019 (di akses pada tanggal 08 April 2019). 
Budiono, (2002), Ekonomi Mikro. Yokyakarta BPFEUGM

Damariyah. (2015). Pengaruh Modal Kerja, Lama Usaha, Jam Kerja, Lokasi Usaha Dan Tingkat Pendidikan Terhadap Pendapatan Pedagang (Studi Kasus di Pasar Desa Pandansari Kecamatan Warungasem. Skripsi. Hal 98-99 Pekalongan: Sekolah Tinggi Agama Islam Negeri (STAIN) Pekalongan.

Gilarso. (1992). Ekonomi Mikro "Suatu Pen- dekatan Praktis". Jakarta: Gramedia Pustaka Utama.

Irawan dan Suparmoko. (1992). Ekonomi Pembangunan. Edisi kelima. Yogyakar- ta: BPFEUGM.

Sukirno, Sadono. (2000). Ekonomi Pem- bangunan Proses, Masalah, dan Dasar Kebijakan Pembangunan. UI-Press. Jakarta.

Swasta, Basu dan Irawan. (2008). Mana- jemen Pemasaran Modern. Yogyakarta: Liberty.

Samuelson, Paul A \& William Nordhaus, (2003). Makroekonomi, Edisi 14. Jakarta: Erlangga.

Sudirman, S., \& Alhudhori, M. (2018). Analisis Sektor Unggulan dalam Meningkatkan Perekonomian dan Pembangunan Wilayah Provinsi Jambi. JMAS (Jurnal Manajemen dan Sains), 3(1), 94-107. 